\title{
Future Gold Commodity: Indonesian Ulema Council Vs Lajnah Daimah lil Buhuts al-'Ilmiyyah wal Ifta
}

\author{
Ayu Rahayu Nurhalizah', Ach. Fageh² \\ ${ }^{1}$ State Islamic University Sunan Ampel Surabaya, Indonesia \\ e-mail: ayurahayunurhalizah6@gmail.com \\ ${ }^{2}$ State Islamic University Sunan Ampel Surabaya, Indonesia \\ e-mail: ach.fageh@uinsby.ac.id
}

\begin{tabular}{|l|l|l|}
\hline Received: 14-05-2021 & Revised: 18-11-2021 & Accepted: 18-01-2022 \\
\hline
\end{tabular}

\begin{abstract}
Technological developments have made it easier to buy gold. Buying gold in installments or online is currently a trend and growing in Indonesia. Buying and selling transactions like this have not been explained in detail in classical fiqh. This research is a normative research with a comparative approach, namely comparing the laws of a country with the laws of one or more other countries regarding the same case. The data analysis techniques used in this article are in the form of data reduction, data presentation, and drawing conclusions. The results of this study state that there are differences of opinion between the Indonesian Ulema Council and the Saudi Arabian Fatwa Institute. The Saudi Arabian fatwa institution issued a fatwa regarding the probibition of buying and selling gold in futures, because gold is a type of usury property and contains 'illat as a unit of price or means of payment. Meanwhile, the National Sharia Council of the Indonesian Ulema Council stipulates a fatwa regarding the permissibility of buying and selling gold in cash or futures, because at this time, gold is no longer a price (tsaman), but gold is an ordinary merchandise or commodity. The discussion about buying and selling gold is in the realm of ijtihad, which is inseparable from differences of opinion (khilafiyah), because there is no definite text in this matter.
\end{abstract}

Abstrak: Perkembangan teknologi semakin mempermudah dalam pembelian emas. Pembelian emas dengan cara dicicil maupun secara daring saat ini sedang tren dan berkembang di Indonesia. Transaksi jual beli seperti ini belum dijelaskan secara mendetail dalam fiqh klasik. Adapun penelitian ini merupakan penelitian normative dengan pendekatan komparatif yaitu membandingkan undang-undang suatu negara dengan undangundang dari satu atau lebih negara lain berkenaan dengan perkara yang sama. Teknik analisis data yang digunakan pada artikel ini yaitu berupa reduksi data, penyajian data, dan penarikan kesimpulan. Hasil dari penelitian ini menyatakan adanya perbedaan pendapat antara Majelis Ulama Indonesia dengan Lembaga Fatwa Arab Saudi. Lembaga Fatwa Arab Saudi mengeluarkan fatwa mengenai keharaman jual beli emas secara berjangka, sebab emas merupakan salah satu jenis harta riba dan mengandung 'illat sebagai satuan harga atau alat pembayaran. Sedangkan Dewan Syariah Nasional Majelis Ulama Indonesia menetapkan fatwa mengenai kebolehan jual beli emas secara tidak tunai ataupun berjangka, sebab emas pada masa ini tidak lagi menjadi harga (tsaman), namun emas sebagai barang dagangan biasa atau komoditas. Pembahasan mengenai jual beli emas masuk pada ranah ijtihad, yaitu tidak terlepas dari perbedaan pendapat (khilafiyah), sebab tidak ada nas yang pasti dalam masalah ini.

Keywords: Gold Commodity, Lajnah Daimah lil Bubuts al-'Imiyyah wal Ifta, Indonesiaan Ulema Council.

\section{INTRODUCTION}

$\boldsymbol{I}$ thas been agreed by all scholars of fiqh that the law of transactions in muamalah is permissible (permissible) unless there is evidence that prohibits it. In a sense, muamalah transactions are not said to 
be haram or prohibited as long as there is no determination of the valid evidence that prohibits it. As Allah says in the Quran: 9: 9, which reads:

$$
\text { قل أرعيتم ماأنزل الله لكم من رزق فجعلْتم منه حراما }
$$

Meaning: Say: "Explain to me the provision that Allah has sent down to you, then you make some of it unlawful and (some) lawful." Say: "Has Allah given you permission (about this), or do you invent against Allah?"

There are indications in the verse that explain that Allah gives freedom and flexibility to muamalah activities. On the other hand, the existence of Shari'a can become a reference and guide for the development of modern transactions as it is today.

According to Yazid (Afandi, 2009), the times that can demand economic development to follow its rhythm also impact muamalah activities such as buying and selling transactions. The sale and purchase are valid if certain conditions are met. These conditions relate to the person making the contract, the object of the contract, and the shigat. The prohibition against buying and selling is the element of speculation (maisir) that can hinder the potential for muamalah properly. With the development of civilization, progress in science and technology (science and technology) by conducting buying and selling transactions through internet media can impact the fields of law, economy, society, culture, and politics. One of them is the futures market which is a supporter of the world economy.

Mohammad Samsul (2010) stated that Indonesia has a futures commodity exchange known as the Jakarta Futures Exchange (JFX), which has received official permission since November 21, 2000, and officially started transaction activities on
December 15, 2000. The futures goods market or Futures Exchange is a business entity that organizes and provides a system and facilities for buying and selling commodities based on futures contracts and options on futures contracts. Commodity exchange is the first discovery between supply and demand for commodities and their derivatives. The sellers and buyers of commodity goods meet at the exchange. Generally, commodities are transacted by CPO (Crude Palm Oil), metals (gold, silver, nickel), coffee, and so on. The scope of this futures contract is spot price, delivery contract, and futures contract (Komoditas, 2021). For every commodity whose contracts are traded on the exchange, the specifications are clearly defined, concerning the quantity, quality, and delivery time, so that exchange users can easily carry out their transactions. This is inseparable from the current unstable economic condition. Conventional investment instruments such as stocks, bonds to the property are very risky. There is no physical delivery of goods in the derivatives market, but settlement in cash, namely the difference between the selling price and the purchase price to be paid or received (Samsul, 2010).

Buying and selling transactions like this have not been explained in detail in classical fiqh. Islamic teachings explain that according to the principle of muamalah, buying and selling, which is equivalent to gold (dinar) and silver (dirham), must be carried out in the same type to avoid riba transactions (riba fadl), as explained in the hadith below (al Bukhari, n.d.):

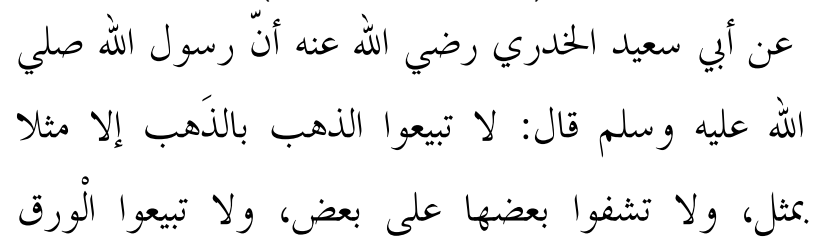


بالْورق إلا مثلا بمثل، ولا تشفوا بعضها على بعضٍ، ولا

$$
\text { تبيعو ا منها غائبا بناجز (متفق عليه) }
$$

Meaning: From Abi Said al-Khudri ra: Rasulullah saw. said, do not sell gold with gold except that which is comparable and do not add part upon the part of another, do not sell silver with silver except that which is comparable and do not add part upon the part of another, and do not sell silver that is not visible with that which is visible. (Hadith narrated by Muttafaq' alaih)

The hadith above explains that it is permissible to buy and sell with the principle of justice. That everything must be paid for with the equivalent or the same value. For that must be paid in cash or cash so that the value is equal. In the future, it may be that the value has changed or been different; it must be equalized so that there is no problem with adding value, which harms one party. Through its institution, the Indonesian Ulema Council, the government itself has regulated the sale and purchase of gold in detail as stated in the DSN MUI fatwa No. Ordinary trading or buying and selling murabahah, the law is permissible (permissible) as long as gold is not an official medium of exchange (money). Meanwhile, according to the Saudi Arabian fatwa Lajnah Daimah lil Buhuts al-'Ilmiyyah wal Ifta' about buying and selling by telephone, it is prohibited by law.

Meanwhile, Fitri stated (2020), if associated with the opinion of scholars who refer to the hadith above, states that the sale and purchase of gold is not cash or futures is not allowed because gold is categorized as ribawi goods that must be cash in the exchange transaction. Among the scholars who forbade the sale and purchase of gold cashless is Imam Shafi'i, Imam Nawawi, Ibn Rusyd, Shaykh Zakaria al-Anshari, Shaykh Abdullah bin Sulaiman al-Mani, and Dr. Wahbah Zuhayli.
Based on the author's desire to know where the root of the problem is, the source of the difference, then which opinion is closest to the truth so that it is worth following and what solutions can be offered to solve this problem. This study seeks to unravel the knots of the issue by trying to raise this discourse by studying the theory of buying and selling cash, not cash, in the constellation of jurisprudence with the title Future Gold Commodity: Indonesian Ulema Council Vs. Lajnah Daimah lil Buhuts al'Ilmiyyah wal Ifta'.

\section{RESEARCH METHODS}

The type of research used in this study is a type of normative research with a comparative approach, which compares the laws of a country with the laws of one or more other countries concerning the same matter. The primary data in this study is related to the sale and purchase of non -cash gold, namely Fatwa DSN MUI No. 77/DSN- MUI/V/2010 on Sale and Purchase of Gold Without Cash and Fatwa of Saudi Arabia (Lajnah Daimah lil Buhuts al-'Ilmiyyah wal Ifta') Number 3211 On Sale and Purchase of Gold by Telephone. The data collection technique used is to collect literature documentation from articles, journals, and books related to the discussion in this study. Data analysis techniques used in this article are data reduction, data presentation, and concluding from the three processes of data analysis that can later eliminate data that is not related to the formulation of the problem to answer the problems in this study. 


\section{RESULTS AND DISCUSSION}

\section{Gold Commodity Futures Business According to Islam}

Gold is one type of precious metal classified as a commodity that is most in demand by the public, especially as a store of value or investment. The World Gold Council (WGC) is the leading market development organization for the gold industry and is a global authority on the gold market. WGC works with a large and diverse set of partners to create access to, and provide insight into, the international gold market, as well as helping people to understand the quality of gold investment and its role in meeting the social and environmental needs of society. In this regard, gold demand has historically been positively correlated with economic growth. The various uses of gold include jewelry, technology, central banks, and investment instruments. The following is described in a total gold demand grouped by mine production, recycling, and producer hedging.

The price of gold is usually directly proportional to the rate of inflation and changes in currency values (usually, the reference is the American currency, the US dollar). The use of gold as a commodity trading subject can be used as a means of hedging because its fluctuations tend to follow currency values (Gunarsa, 2019).

Pic 1.

The price of gold is directly proportional to the rate of inflation

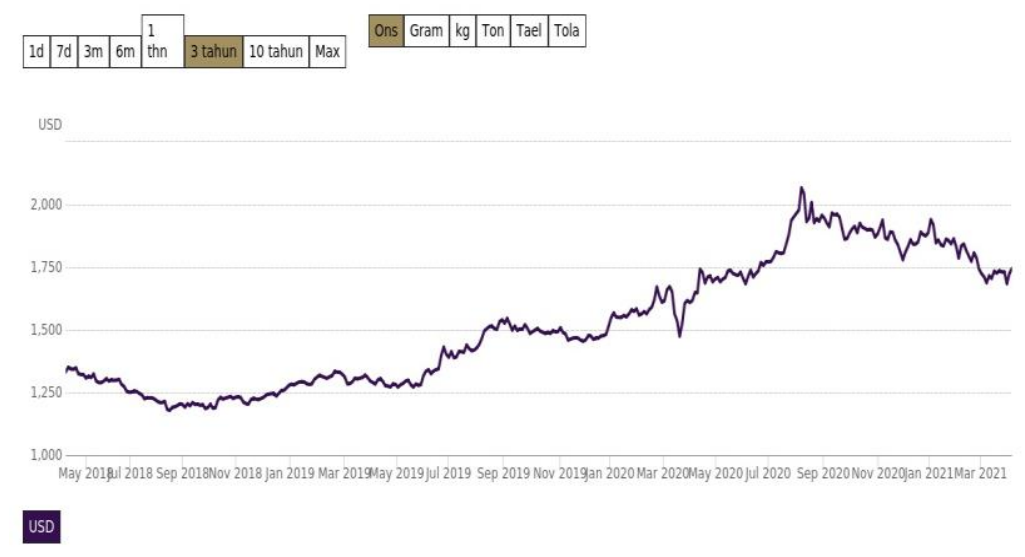

Source: www.gold.org

With the growth of the gold price, which is relatively rising from year to year, the gold buying and selling business is in great demand. This is inseparable from the unstable economic condition as it is now. Conventional investment instruments such as stocks, bonds to the property are very risky. The choice of buying and owning gold can be made on credit to meet the demands of people who do not have sufficient funds but want to own gold. 
Pic 2.

Comprehensive gold demand grouping chart

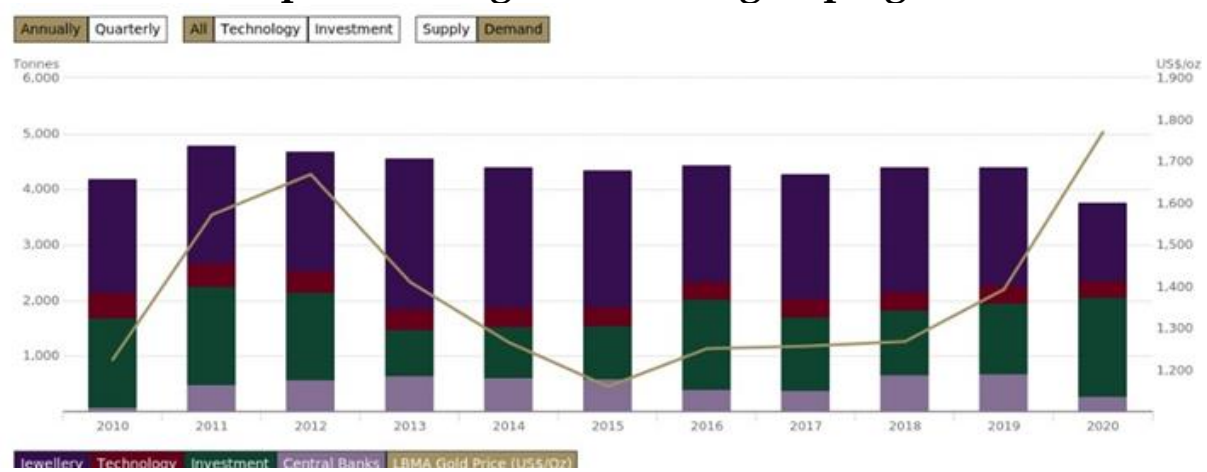

Source: www.gold.org

Exchanging gold for gold must meet the requirements of taqabudl, tamatsul, and Hulul. Taqabudl is an agreed handover between the price and the goods. Tamatsul agrees in equal measure and weighing. And Hulul knows the maturity/payment period. If the sale and purchase are carried out between two dissimilar riba goods (mukhtalifay al-jinsi), it is obligatory to meet the requirements of taqabudl and Hulul.

The problem is, what if the practice of buying and selling gold is carried out in the futures/derivatives market? Of course, the buying and selling system in this derivative market is that physical gold goods are not displayed directly but only in the form of index values of an underlying asset. Therefore, it is inevitable that prices and goods cannot be directly transferred in this trading system. As a result, no cash is the norm. In Islam, every sale and purchase is carried out through indirect acceptance, and there is a time lag between the delivery of the price and the goods. This kind of sale is included in the group of tempo trading (bai' bi al-ajal), or sale and purchase of greetings (message contract). . Because the nature and content of the goods are also known, even though it is in the form of an index value record which specifically contains an explanation of the characteristics of the products being sold, the practice of buying and selling goods with known characteristics is also known as bai syaiin maushuf fi aldzimmahi.

What is the law of all that when applied to the practice of buying and selling gold in the futures market? This is the interesting side. This is because many parties state that the meaning of taqabudll and Hulul is defined as mandatory cash and direct handover of prices and goods at the contract assembly. If you follow this kind of concept of cash, then it is your right, and of course, there are risks in practice. One of the risks is that if you buy gold, you have to come to the gold shop directly. The shop is also obligated to do the same, namely if they want to buy gold for stocking traded goods, they are not allowed to order it by telephone and the like. They must come personally to where the gold is formed and made into jewelry (huliyyin mubah). Once the gold has been printed, the shop must also submit the price directly. It's a hassle if all these practices have to be done, and it seems it's impossible for traders who sell gold to implement it.

In the Shafili school, the law of debt gold with a return of gold is permissible without any mistakes among the scholars. The rule of the game is that the gold that is owed with the gold used to pay off the debt must have the same grade and weight. The 
debt of $1 \mathrm{~kg}$ of gold, then the return of $1 \mathrm{~kg}$ of gold must also be, no more, no less. If more of one of them is exchanged or returned, then there is no doubt that the excess is entered into the concept of riba contract. In debt, riba is called riba qardli, and in cash sales, riba is riba al-fadhli. However, because the delivery requires a time, then in terms of buying and selling, the excess in one of the goods accompanied by the delivery time is included in riba al-yadd. If the time of the delivery contract is known and there is an increase in line with the new tenor, then the excess is called riba. al-nasiah. In the gold debt contract, it is necessary to have physical gold that changes, even though the grade and size are the same. The existence of a physical change indicates an exchange contract ( $m u^{\prime}$ awadlah) which is the basis of a sale and purchase contract (barter). Whether of the same type or not, the exchange between physical goods and carried out directly at the contract assembly is another term for a cash sale and purchase contract (halan).

Meanwhile, the contract for exchanging physical goods accompanied by a time lag (tempo), either with a short or long time lag, indicates that a sale and purchase contract with a tempo (bai' bi alajal) has occurred. If the time lag is known, it includes buying and selling credit (nasiah). As a result, the gold debt contract is the same as a tempo sale and purchase contract or a bai nasa' contract (credit sale and purchase).

The tempo sale contract is another term for the current trading contract, known as a commodity futures trading contract. It is legally valid as long as there is no element of riba, gharar (speculative), maisir (gambling), and ghabn (cheating). So, futures trading (bai' bi al-ajl) is a trade that is accepted by the Shari'a concept. The price that has not been paid at the contract and when the goods are handed over to the buyer, then the price in its fiqh position is the price owed. And this applies to tempo trading.

Conversely, goods that have not been delivered at the time of the contract and the price ( $R a^{\prime} s$ al-mal) to the seller, then the goods in their figh position are in the position of the goods owed. Fiqh calls it syaiin fi al-dzimmah (goods that are guaranteed debt). This kind of thing applies to the sale and purchase contract pre-order (bai' as-salam).

Comparative Analysis of Fatwa of the National Sharia Council of the Indonesian Ulema Council No. 77/DSNMUI/V/2010 About Futures Gold Commodity with Fatwa of Saudi Arabia (Lajnah Daimah lil Buhuts al-'Ilmiyyah wal Ifta) Number 3211 About Buying and Selling Gold Over the Phone

\section{According to the Fatwa of the National Sharia Council of the Indonesian Ulema Council No. 77/DSN-MUI/V/2010 \\ The National Sharia Council of the Indonesian Ulema Council issued a fatwa Number 77/DSN-MUI/V/2010 concerning the sale and purchase of gold without cash which states that the sale and purchase of gold without cash is permissible or permissible as long as gold is not an official medium of exchange (currency) (Dewan Syariah Nasional, 2010)}

The arguments that form the basis of the law of the ability to buy and sell gold in non -cash, namely:

Hadith narrated by Ibn Majah and al-Baihaqi from Abu Said al-Khudriy;

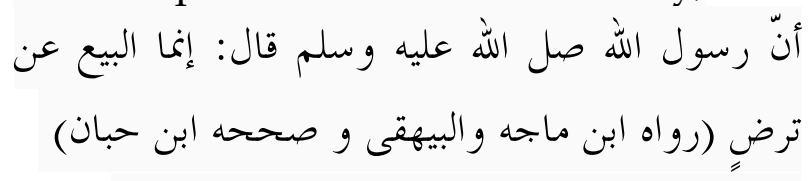

The Prophet SAW. said: indeed, the sale and purchase are based on voluntariness (both parties). (Hadith 
narrated by Ibn Majah and al-Baihaqi and judged authentic by Ibn Hibban)

Hadith narrated by Tirmidhi from Amr bin Auf al-Muzani, the Prophet SAW said;

$$
\begin{aligned}
& \text { الصاح جائز بين المسلمين إلّا صلحا حرم حلالا أو } \\
& \text { أحل حرما والمسلمون على شروطهم إلّا شرطا حرم } \\
& \text { حلالا وأحل حراما }
\end{aligned}
$$

Meaning: Peace can be made between Muslims except for peace that forbids the lawful or legalizes their conditions bind the unlawful, and Muslims except for the conditions that forbid the halal or legalizing the haram.

The National Sharia Council of the Indonesian Ulema Council believes that the above hadiths are laws that contain 'illat. 'Illat is something that can change the situation, meaning that gold in ancient times was a tsaman (price, medium of exchange, or means of payment). However, gold is no longer a price or a means of payment in the current condition, so the law is not the same. This is related to the rules of ushul:

$$
\text { الحكم يدور مع علّته وجودا و وعدما }
$$

Meaning: The law rotates (applies) along with the presence or absence of 'illat.

And the rules of fiqh:

$$
\begin{aligned}
& \text { كل" حكم مرتب على عرف أو عادة بيطل عند زوال } \\
& \text { تلك العادة، فإذا تغيّر الحلكم تربم }
\end{aligned}
$$

Meaning: Every law that is based on an 'urf or custom (community custom) becomes void (does not apply) if the custom is lost, then if the custom changes, the law also changes

Sheikh Ali Jumu' ah argued that the sale and purchase of gold and silver that has been made or prepared to be made with payment in installments is permissible because gold and silver are no longer valid as a medium of exchange in society, and both have become goods like other goods traded in cash nor cash (M. Ichwan Sam dkk, 2014)

According to the opinion of several contemporary scholars above, buying and selling gold in cash is permissible because of the times that have made gold no longer a medium of exchange or means of payment, but gold as an item as it is traded as usual.

On June 3, 2010, through the plenary meeting of the National Sharia Council of the Indonesian Ulema Council in Jakarta, that buying and selling gold in cash is allowed with the following limitations and conditions (Dewan Syariah Nasional, 2010):

First: The law of buying and selling gold in cash, either through ordinary buying and selling or selling murabaha, is permissible (permissible) as long as gold is not an official medium of exchange (money).

Both Limitations and Conditions: (1) The selling price (tsaman) may not increase during the term of the agreement even though there is an extension of time after maturity; (2) Gold purchased with non-cash payments may be used as collateral (rahn); (3) Gold that is used as collateral as referred to in number 2 may not be traded or used as the object of another contract that causes the transfer of ownership.

\section{According to Fatwa of Saudi Arabia (Lajnah Daimah lil Buhuts al-'Ilmiyyah wal Ifta) Number 3211}

Sheikh Abdul Razik Ahmad Hasan's book (Hasan, 2005) argues that paper money is a branch of gold and silver, so it can be said that gold and silver with paper money is one type. Therefore, buying and selling between one type of goods with non-cash payments is included in riba nasi'ah. 
Saudi Arabia's fatwa agency (adDausy, n.d.) (Lajnah Daimah lil Buhuts al'Ilmiyyah wal Ifta) based on question number 3 Fatwa Number 3211 regarding the law of buying and selling gold over the phone, which has the nature of buying and selling gold online, answered that buying and selling gold over the phone is an unlawful transaction because money as a means of payment and gold are the same type (tsaman with tsaman) as well as delays in the handover of goods or payments. So the transaction is included in the category of riba nasi'ah. The allowed sale and purchase of gold is the payment of the price following the seller's agreement, and the buyer and the handover are carried out directly on the spot or in cash.

Riba means additional, meaning that it is an addition to the basic price, whether in small or large quantities (Sayyid Sabiq, 2009). Jumhur scholars divide riba into two types, namely riba nasi'ah and riba fadhl. Riba nasi'ah, as explained by Imam Qatadah is as follows (Sayyid Qutub, 2018):

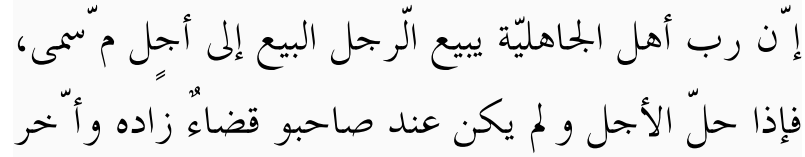

Meaning: Riba is done by ignorant people, namely someone sells his merchandise with a predetermined payment time, then when it is due and the buyer has not been able to pay it off, the seller increases the price and extends the payment deadline.

The definition of riba nasi'ah based on the above understanding is a sale and purchase transaction of similar or other types of goods with the addition of a price from the basic price due to an extension of the payment deadline. Meanwhile, riba fadhl according to Sayyid Qutub (Qutub,
2018), is a transaction of buying and selling goods that are similar to the addition of value to one of the types of goods.

The law of riba is unlawful. The evidence that explains the prohibition of riba, is as follows in the Quran: 2: 275 and Quran: 3: 130, which reads:

$$
\text { وَأَحَلَّ اللَّهُ الْبِهِع وَحَرَّمَ الرِبِا }
$$

Meaning:... Allah has permitted trading and forbidden riba.

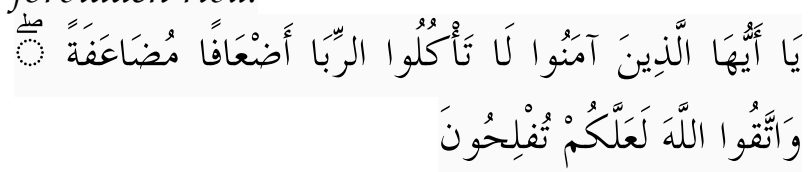

This means: you who believe, do not consume riba with double profits, and fear Allah, then you will be among the successful.

Then some hadiths that prohibit riba transactions are as follows (Al-Asqalani, 2002):

$$
\begin{aligned}
& \text { روى البخارى ومسلم عن أبى عريرة أَّن البي صلى } \\
& \text { الله عليه وسلم قال: اجتنبوا السبع الدوبقات. قالوا: } \\
& \text { وما ى نّ يَ رسول الله؟ قال: الشرك بلله، والسحر، }
\end{aligned}
$$

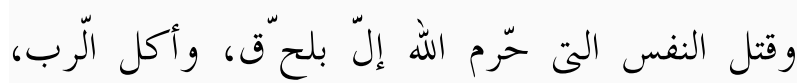

$$
\begin{aligned}
& \text { وأكل مال اليتيم، والتول يوم الزحف، وقذف النف بلح } \\
& \text { الخصنات الغافلات الدؤمنات }
\end{aligned}
$$

Meaning: Hadith narrated by Bukhari and Muslim, from Abu Hurairah that the Prophet $S A W$. said: Stay away from the seven kinds of great sins. They asked: What are the seven things, $O$ Messenger of Allah? He said: Associating partners with God, magic, illicitly killing souls, riba, consuming the property of orphans, fleeing from the battlefield, and accusing of adultery holy women who have married because of their negligence.

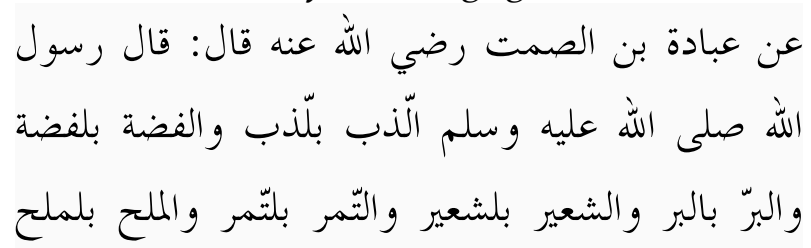




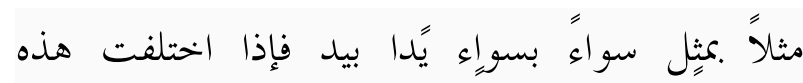
الأصناف فبيعواكيف شئتم إذاكان يُّاء بيد. بيداء (رواه

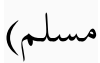

Meaning: From Ubadah bin ash-Shamit ra: Rasulullah saw. said (It is permissible to sell) gold for gold, silver for silver, wheat for wheat, jawawut for jawawut, dates for dates, and salt for salt, which are equally comparable, of a kind, and in cash. (Hadith narrated by Muslim)

Based on the hadiths above, it is clear that buying and selling gold in cash is a riba transaction. Transactions of riba goods can be carried out on condition that the amount and amount must be the same as well as cash delivery at the time of the transaction, buying and selling between different types of riba goods with different amounts and levels may be on condition that the delivery is done in cash, sale and purchase of riba goods with non-ribawi goods are not required to be the same in amount or delivery at the time of the transaction.

Fatwa of the National Sharia Council Number 77/DSN-MUI/V/2010 on the Non-Cash Sale and Purchase of Gold with the fatwa of Saudi Arabia (Lajnah Daimah lil Buhuts al-'Ilmiyyah wal Ifta) Number 3211 On the Sale and Purchase of Gold by Phone have differences of opinion on selling buy non cash gold or gold commodity futures.

Dewan Syariah Nasional, in its fatwa stipulates the ability to buy and sell gold in a non -cash manner, as long as gold does not become an official medium of exchange or payment. The fatwa is the result of ijtihad from contemporary scholars such as Ibn Taymiyyah and Ibn Qayyim. The institution of Lajnah Daimah lil Buhuts al-'Ilmiyyah wal Ifta issued a fatwa that buying and selling gold in cash is an illegal transaction because gold is included in the category of ribawi goods according to Islamic evidence, 'illat because gold is a unit of price or payment instrument like money on this time.

The point of similarity between the fatwa of DSN MUI and the fatwa of Saudi Arabia is gold which is one of the types of ribawi goods based on the hadith of the Prophet saw, whose transactions are performed directly. The National Sharia Council of the Indonesian Ulema Council and the fatwa board of Saudi Arabia both studied the law of gold trading using evidence found in the Quran, hadith, and consensus.

The discussion on the sale and purchase of gold enters the realm of ijtihad, which is inseparable from differences of opinion (khilafiyah) that may be wrong or true because there is no definite text in the matter. In comparison, the difference is something that is sunatullah in human life. Taking and using one of the opinions that the caliphate, God willing, is true unless you use it to follow lust alone and cause slander, then it becomes haram.

\section{CONCLUSION}

The transaction of buying and selling gold on a non -cash or commodity gold futures basis raises a difference among scholars between the opinion that allows and the opinion that prohibits. The fatwa board of Saudi Arabia issued a fatwa on the prohibition of trading gold in non -cash or futures because gold is one type of usurious property and contains 'illat as a unit of price or means of payment. In comparison, the National Sharia Council of the Indonesian Ulema Council set a fatwa on the ability to buy and sell gold in futures because gold is 
no longer a price (tsaman) but gold as a common commodity.

But in principle, all forms of muamalah practice are permissible as long as they do not violate the rules that the syariah has outlined. The provisions that apply to the practice of buying and selling ribawi goods are obligatory taqabudl and tamatsul, with the typical characteristics of the price or goods that have been agreed upon in the exchange provisions when in the contract assembly. The absence of the practice of muamalah, from fulfilling the provisions of the exchange allowed by the Shari'ah, makes the exchange law prohibited.

\section{REFERENCES}

Ad-Dausy, Syekh Ahmad bin Abd arRozaq. (n.d.). Fatawa Lajnah Daimah lil Buhuts al-'Ilmiyyah wal Ifta, Jilid VII.

Afandi, Y. (2009). Fiqih Muamalah. Logung Pustaka.

Al-Asqalani, I. H. (2002). Bulughul Maram min Adillah al-Ahkam. Dar ash-Shidiq.

Al-Bukhari, I. (n.d.). Sahih al Bukhari: Kitab al-buyu' (Cetakan ke). Dar al-Fikr Hadis dari Abu Said al Khudri.

Armen, R. (2021). Analisis Hukum Islam Terhadap Jual Beli Emas Secara Tidak Tunai. Zhafir | Journal of Islamic Economics, Finance, and Banking, 2(1), 15-32.

https://doi.org/10.51275/zhafir.v2i1. 177.

Dewan Syariah Nasional. (2010). Fatwa Dewan Syariah Nasional Nomor: 77/DSN-MUI/V/2010 Tentang Jual Beli Emas Secara Tidak Tunai.

Gunarsa, S. M. (2019). Kontrak Berjangka Komoditas Emas Sebagai Instrumen Transaksi Derivatif dalam Kajian Hukum Ekonomi Syariah, Undang: Jurnal Hukum, Vol. 2(1). https:/ / doi.org/10.22437/ujh.2.1.95-
117

Hasan, A. (2005). Mata Uang Islami. PT Raja Grafindo Persada.

Komoditas. (2021). Wikipedia. http://id.wikipedia.org/wiki/Komo diti

Qutub, S. (2018). Tafsir Ayat-Ayat Riba, terj. Ali Rohmat. Wali Pustaka.

Sam, M. I., (2014). Himpunan Fatwa Keuangan Syariah Dewan Syariah Nasional MUI. Erlangga.

Samsul, M. (2010). Pasar Berjangka Komoditas Dan Derivative. Salemba Empat.

Sabiq, S. (2009). Figh Sunnah. Dar al-Fath li I'lam al-Arabi. 